\title{
RENOVATION AND RECONSTRUCTION \\ OF A NEOCLASSICAL BUILDING ON THE EXAMPLE OF A PUBLIC CITY LIBRARY IN NOWA SÓL
}

\author{
Anna KUCHARCZYK ${ }^{1}$ \\ University of Zielona Gora, Zielona Góra, Poland
}

\begin{abstract}
The building of the Nowa Sól public library is located on Bankowa Street, in the Lubuskie Voivodeship. The new seat of the library has been here since 2011; it had previously been located in the building on Parafialna and Szkolna Streets, which did not comply with the requirements of a comfortable library and reading room. Renovations and reconstructions of this neoclassical building began in 2007 and took four years to finish. Over the years, the century- old building had changed, its function - from a residential villa, to a children's hospital, and finally, a clinic for children. During construction works, rib and slab (Ackerman) floors were changed to concrete slabs with higher load-bearing strength and roof truss system replaced to accordingly to the original design. A new lift was built, and the library reading rooms and archives were expanded. The building also gained a new facade as well as new wooden windows and doors. The entire building is surrounded by a park.
\end{abstract}

Keywords: Public Library, Nowa Sól, renovation and reconstructions, neoclassical architecture.

\section{NEOCLASSICISM IN ARCHITECTURE}

The term neoclassical describes various tendencies referring to ancient classicism. In English- and French-speaking countries, the term at hand was

\footnotetext{
${ }^{1}$ Corresponding author: University of Zielona Gora, Faculty of Building, Architecture and Environmental Engineering, Z. Szafrana st 1, 65-516 Zielona Góra, Poland, e-mail: a.kucharczyk@ib.uz.zgora.pl, tel. +48683287803
} 
applied interchangeably to classicism in the middle of the XVIII century as a movement in direct opposition to baroque architecture.

The neoclassical school made the biggest impact in areas where the not popular enough opulence of rococo or baroque began to be replaced with solutions typical of antique architecture, stemming mainly from ancient Greece. Here, the mentioned replacement took the form of simplicity and moderation connected with the lightness of the entire building.

The main characteristics of the neoclassical movement [1]:

- applying the orders of ancient architecture,

- modeled on buildings of Greek and Roman architecture,

- buildings constructed on the compact layout of a circle or rectangle,

- application of colonnades and column porticos,

- aiming to achieve the effect of harmony, symmetry and a balanced composition,

- linear facades,

- limited ornamentation.

\section{HISTORICAL BACKGROUND OF THE CITY PUBLIC LIBRARY BUILDING IN NOWA SÓL}

Nowa Sól is the third in terms of size district (poviat) city in the Lubuskie voivodeship, located on the strip of the Trzebnicki Embankment, on the left bank of the Odra River. The city is currently inhabited by approx. 40 thousand people [7] (demographic data as of December 2014), of which approx. $25 \%$ are under working age.

Industry is the dominant role in the region, with culture being poorly developed and insufficiently financed. The young society is revealing increasing needs in terms of education and culture.

The City Public Library (Miejska Biblioteka Publiczna - MBP) building is located on Bankowa 3 Street, with the land property reference number of 604. The former building of the MBP did not guarantee free and comfortable access to its collection. The available area was too small and the reading rooms did not fulfill the needs of the large numbers of readers who used scientific literature, magazines and multimedia [5]; it also lacked space for computer workstations with access to the internet. On top of this, there were many architectural obstacles that posed a problem for the disabled. 


\subsection{Historical background of City Public Library building in Nowa Sól}

The building of the City Public Library in Nowa Sól was constructed in the years 1900-1914. The first owner of the villa was the chief executive officer of the thread factory Gruschwitz Textilwerke - Karl Janson. A city park was created on land properties west of the building that had not been developed, in the years 1927-1930. During World War II, the building was severely damaged; following the war, it was adapted, completely changing the spatial layout of the interior, to a children's ward of the city hospital, which was closed down in 1980. Over the next two years, the building was subjected to renovation work and adapted to serve as a children's specialist clinic and next, non-government health care centers and private residences [3]. Besides documentation in the form of postcards, no documents concerning the design and construction of the building remain.

In 2007, the European Union project to transfer the City Public Library was commenced and reconstruction and renovation works on the building were initiated. The construction works were finished in 2010, and on 1 January 2011, the library began to operate from its new location.

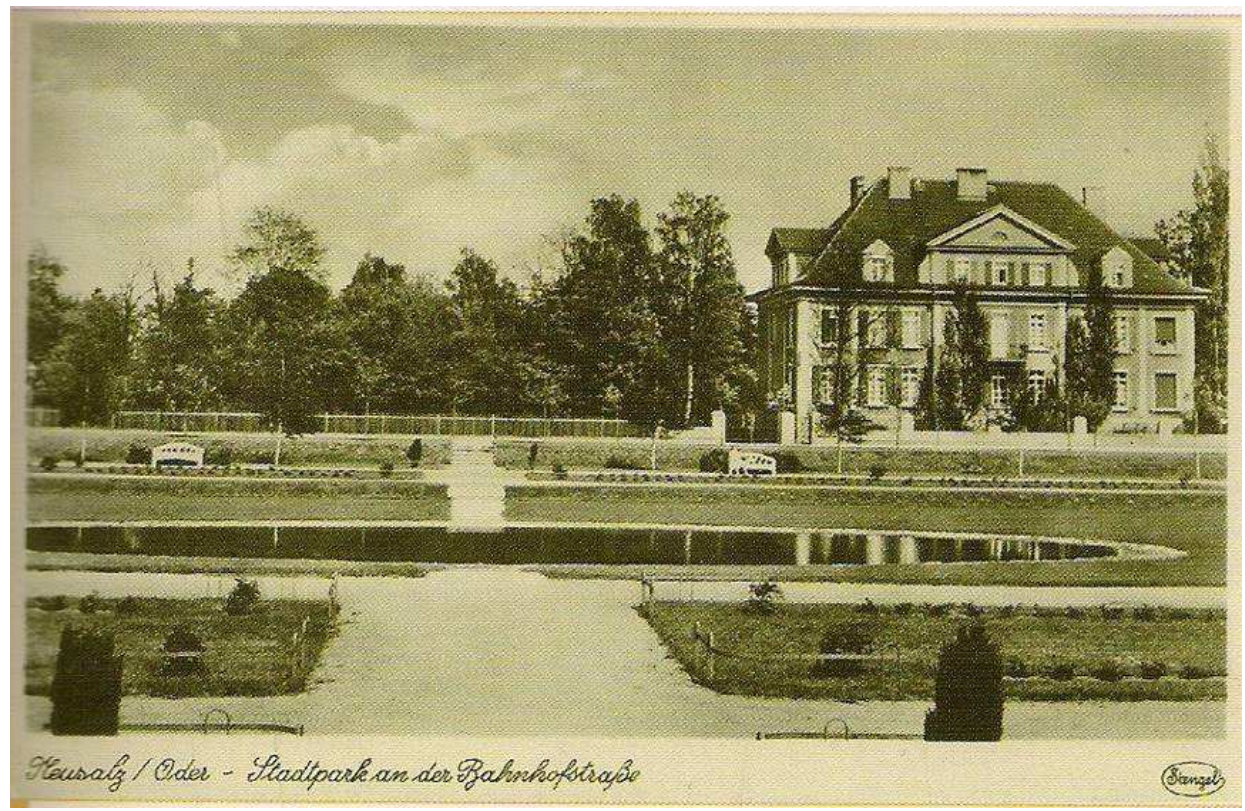

Fig. 1. View of the building from the direction of the city park.

Postcard from the 30's of the XX century. Source: Collection of the City

Museum in Nowa Sól. 


\section{ARCHITECTURE OF THE BUILDING PRIOR TO RENOVATON AND RECONSTRUCTION}

The building had been constructed in a neoclassical style. Along with the surrounding park, it fit the urban landscape of the city on the verge of the XIX and XX centuries ideally, representing a group of residences inhabited by the Nowa Sól factory owners.

The 2-axis northern elevation is divided into fields with pilasters. A 2-axis inset adorned with volutes and crowned with a triangular peak is found in the roof slope. The entry doors are found on the east elevation of the building, along with a single flight of stairs from the ground level, constructed using reinforced concrete technology, whereas the balcony over the stairs is supported by brick pillars. In the south elevation, there is a corridor with an entrance. The basements are on a triangular layout, with the main entrance in an avant-corps on the east side. The ground floor is triangular with a communication system set out in the middle part, and main entrance from the stairwell, also in an avantcorps. The rooms are divided by partition walls, and a sanitary unit can be found in the eastern part. There are entrances from the outhouses in the north and east. The interiors of the upstairs are analogical to those on the ground floor, with balcony entrances on the east and west elevations. From the east, the building is surrounded by the park; some of the property is fenced off with a brick wall, whereas a metal segment fence with two steel decorative gates is present from the direction of Bankowa and Gimnazjalna Streets.

\section{BUILDING CONSTRUCTION PRIOR TO RENOVATION AND RECONSTRUCTION}

The building under study was constructed in traditional technology with a full basement and attic partially used for residential purposes. The building is situated at a depth of $1.20 \mathrm{~m}$ below the ground level. The inside and outside walls were made of solid brick with an adequate strength category of 10-15 (MPa) using cement-lime mortar. Floors are made using rib and slab (alsocalled Ackerman) technology, with cinder blocks $15 \mathrm{~cm}$ in height, reinforced with bars $\varnothing 14$, and concrete slabs $4-5 \mathrm{~cm}$ thick. The stairs inside the building were constructed using reinforced concrete technology. The construction of the roof was made up of queen post trusses and covered in a single layer of plain ceramic pantiles. 
Table 1. Technical data for building

\begin{tabular}{|c|l|c|}
\hline 1 & Building footprint & $425.0 \mathrm{~m}^{2}$ \\
\hline 2 & Building volume & $6252.0 \mathrm{~m}^{3}$ \\
\hline 3 & Height & $17.26 \mathrm{~m}$ \\
\hline 4 & Length $\mathrm{x}$ width & $26.74 \times 15.90 \mathrm{~m}$ \\
\hline 5 & Net surface area & $1270.0 \mathrm{~m}^{2}$ \\
\hline
\end{tabular}

\section{EVALUATION OF THE TECHNICAL CONDITION OF THE BUILDING (BEFORE RECONSTRUCTION)}

Based on the technical evaluation [4] of the building on Bankowa 3, its conditions was determined as average. Upon inspection, cracks were not noted on neither the inside nor outside walls of the basement rooms; however, numerous signs of flooding, from the flood that occurred in 1997, could be observed - the water reached $0.5 \mathrm{~m}$ above the level of the floor. Another observation was that neither the floors nor stairs contained any visible deformations, deflections or cracking, however the existing rib and slab floors spanning over $4 \mathrm{~m}$ did not have enough load-bearing capacity (the storage for books was planned upstairs in the attic, with the collection of books and manuscripts downstairs on the ground floor), in order to fulfill the requirements for rooms where library collections are to be stored. A comparison of service loads for rooms in medical clinics and libraries has been presented below (Tab. 2).

Table 2. Comparison of service loads characteristic for medical clinics and libraries

\begin{tabular}{|c|c|c|}
\hline Types of rooms & Medical Clinics & Libraries \\
\hline Rooms, halls & $2.0 \mathrm{kN} / \mathrm{m}^{2}$ & $2.0 \mathrm{kN} / \mathrm{m}^{2}$ \\
\hline Corridors & $2.5 \mathrm{kN} / \mathrm{m}^{2}$ & $4.0 \mathrm{kN} / \mathrm{m}^{2}$ \\
\hline Stairs & $4.0 \mathrm{kN} / \mathrm{m}^{2}$ & $4.0 \mathrm{kN} / \mathrm{m}^{2}$ \\
\hline Storage rooms/archives & - & $5.0 \mathrm{kN} / \mathrm{m}^{2}$ \\
\hline
\end{tabular}

While carrying out the inspection of the roof trusses, lengthwise splitting of approximately $40 \%$ of the rafters and posts was confirmed, with $20 \%$ in the case of roof purlins and collar ties. Another conclusion was that the crosssections of purlins spaced 3.5-4.5 m apart are insufficient despite the presence of angle braces. The remaining construction elements, such as the foundation, load-bearing and partition walls, and stairs did not require additional strengthening or replacement. 


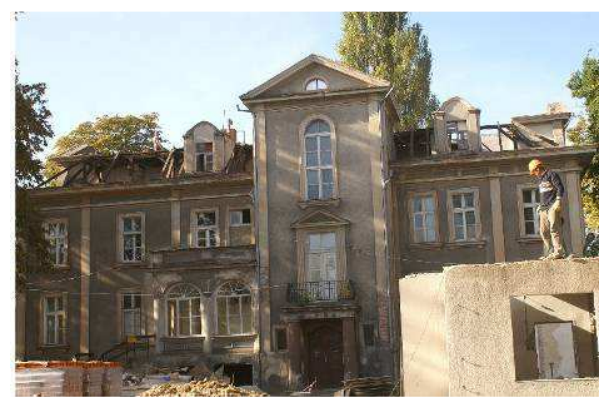

Fig. 2. Building during the taking apart of roof trusses. Source: MBP archives.

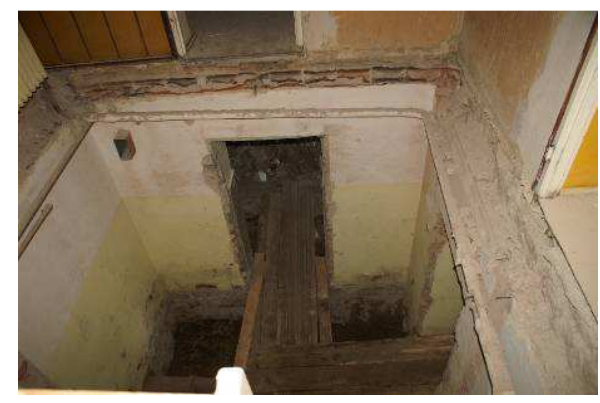

Fig. 3. Removing a part of the old ceiling Source: MBP archives.

\section{BUILDING SOLUTIONS APPLIED DURING THE RECONSTRUCTION}

Considering that the MBP building is on a list waiting to be added to the register of historic monuments, a decision [4] was taken by the Historic Buildings Conservator of the Lubuskie Voivodeship to grant permission for the reconstruction of the building on Bankowa 3. The construction project covered:

- replacing a portion of the ceilings over the basement, ground floor and upstairs,

- the replacement of roof trusses modeled on the existing structure,

- creating two dormer windows in the roof, on the side facing Bankowa Street,

- constructing an elevator and stair platform lift for the disabled inside the building, and a ramp on the outside near the entrance,

- reconstruction of the outside entrance to the basement and removal of outside stairs,

- destroying some of the of inside door openings and creating new ones, along with installing new door elements,

- constructing additional ventilation chimneys,

- lowering the basements floors to a level of -2.80 along with insulating the floor,

- finishing the inside walls, ceilings and floors,

- renovating the wooden elements of the stairwell,

- patching outside plasters, carrying out insulation with bitumen, and paintwork on the facade.

Following reconstruction and revitalization, the body of the building remained unchanged, whereas the inside underwent several changes as a result of 
changing the function the building was to serve and finishing elements. The scope of remodeling work was very broad.

\subsection{Basement rooms}

The basement floor was lowered to a level of -2.80 beneath the level of the ground floor; within the lift pit, the strip foundation was strengthened in segments.

\subsection{Construction of floors}

The existing floors were changed to ones of reinforced concrete, $12 \mathrm{~cm}$ in thickness, using C12/15 (B15) concrete reinforced with bars $\emptyset 8$ of A-I steel, spaced $15 \mathrm{~cm}$ apart, welded to the middle of the beams, supported by IPE 200 and 180 steel beams for floors characterized by smaller spans.

\subsection{Beams}

Beams were made of I 200 steel sections, set on concrete pads made of C12/15 concrete measuring $40 \times 25 \mathrm{~cm}$, additionally stiffened using webs due to twisting.

\subsection{Construction of roof truss system}

A new roof truss construction was made based on the original, additionally creating two dormer windows on the side of Bankowa Street. Class K-27 wood was used. The cross-sections of the truss elements have been provided in Table 3 .

Table 3. Cross-sections of roof truss elements.

\begin{tabular}{|c|l|c|}
\hline No. & \multicolumn{1}{|c|}{ Type of element } & $\begin{array}{c}\text { Cross Section } \\
{[\mathrm{cm}]}\end{array}$ \\
\hline 1 & Ridge beam & $12 \times 18$ \\
\hline 2 & Valley rafter & $12 \times 18$ \\
\hline 3 & Rafter & $10 \times 16$ \\
\hline 4 & Post & $12 \times 12$ \\
\hline 5 & Posts & $10 \times 10$ \\
\hline 6 & Purlin & $12 \times 18$ \\
\hline 7 & Collar ties & $8 \times 16$ \\
\hline 8 & Angle braces & $8 \times 12$ \\
\hline 9 & Tie beams & $12 \times 12$ \\
\hline
\end{tabular}

The roof is covered with two layers of plain type pantile, laid in the "lacing" pattern. 


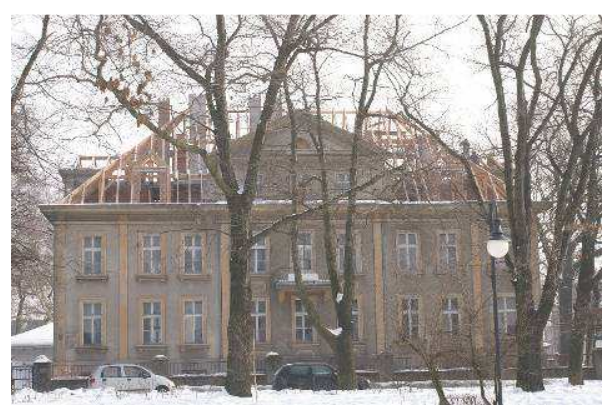

Fig. 4. Replacing the roof truss system Source: MBP Archives.

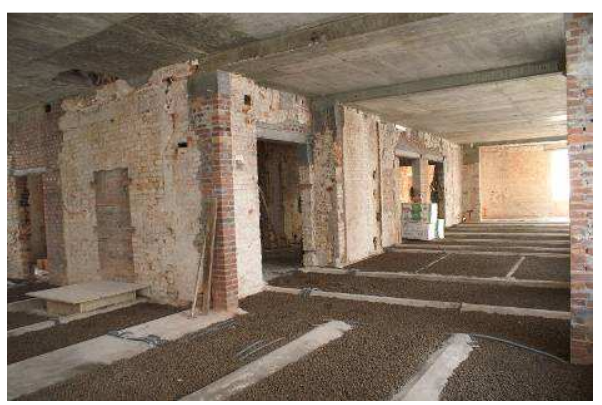

Fig. 5. Construction works on floors. Source: MBP Archives.

\subsection{Demolition and renovation/finishing works}

In addition to renovation works, many demolition works also took place, as the taking apart of interior partitions in order to obtain a bigger surface area, or the outside staircase, which had been added on in the 80 's. Some of the inside door openings were walled up and new ones created in order to adapt the building to its new function. All of the wooden doors and windows were replaced. Some windows, as for example the windows in the stairwell, were renovated [4]. A series of moisture and water protection as well as thermal and acoustic insulations were carried out in the walls and floors of the basement. Due to the historical nature of the building, it did not undergo thermorenovation.
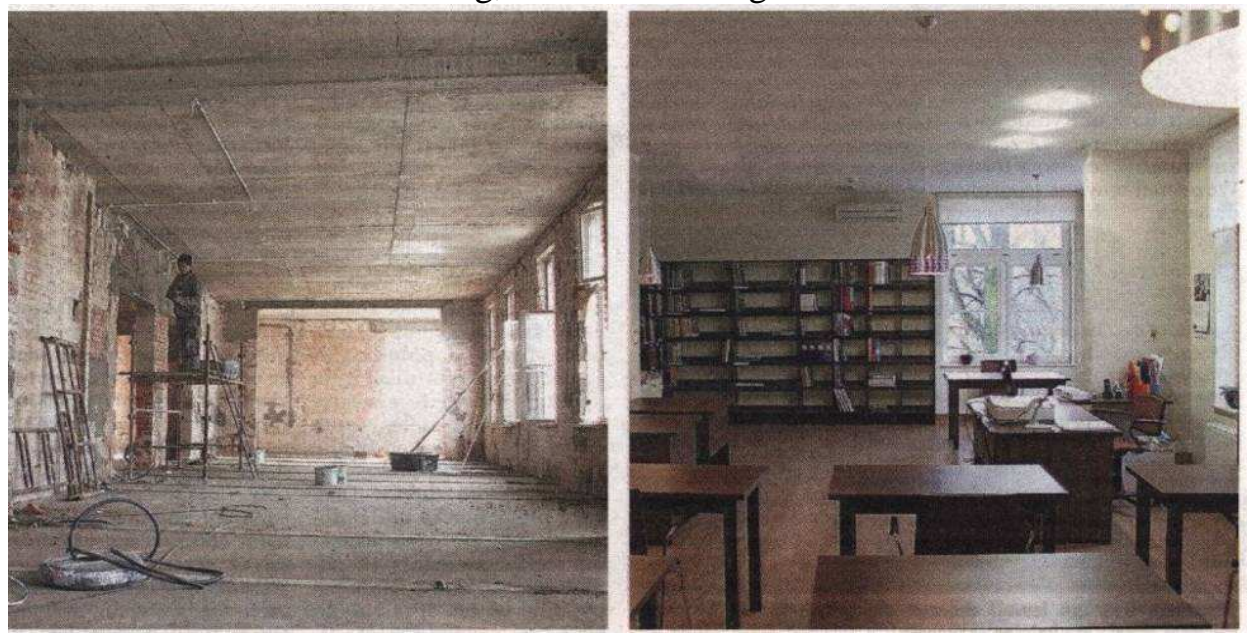

Fig. 6. Reading room at the beginning of construction works (on left) and upon completion (on right). Source: Gazeta Lubuska (Lubuska Newspaper) No. 28, 2011 


\section{CONCLUSIONS}

The new MBP headquarters on Bankowa Street fulfill all qualities, esthetic as well as functional. The building, which had been falling into ruins during the time it functioned as doctors' clinics, was given a "second life". The elevation of the building was beautifully restored providing access to the handicapped and inside rooms were adapted to serve library functions. The library is equipped with modern electronic devices, which facilitate providing fast service to readers, ongoing registration of volumes and using electronic library cards. Halls for organizing book readings, meetings with authors and other cultural events are present in the building. The entire building is surrounded by a green park referred to as the Art Garden, where one can find, among others, a fountain, pergola, mini amphitheater, area for playing chess in the open air and parking places. As a result of such activities, a representative building which has been the home of the MBP since 2011 was created. The previous headquarters had been located in a building near the corner of Parafialna and Szkolna Streets. Despite applying modern devices and technologies, the MBP building has maintained its historic nature.

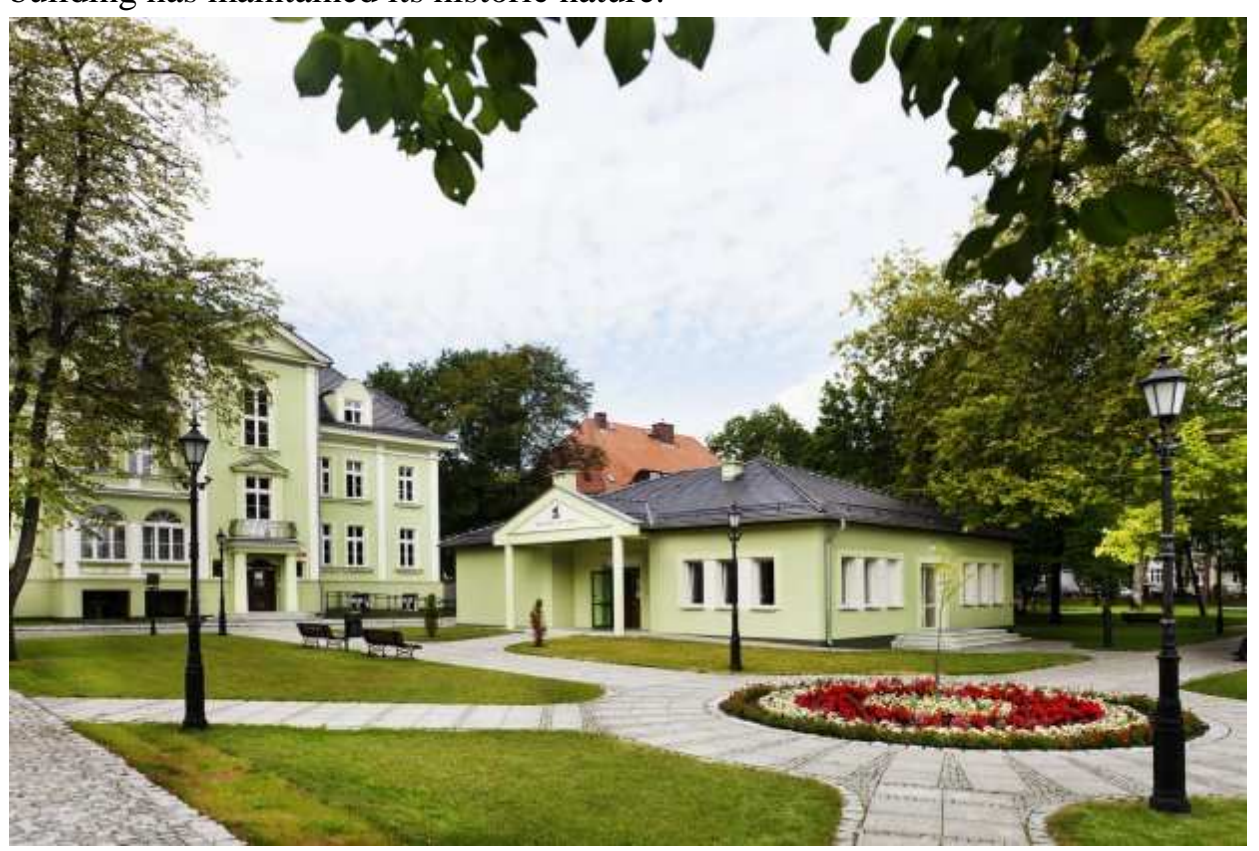

Fig. 6. New headquarters of the City Public Library. Source: Materials of the Marshal Office in Zielona Góra 


\section{ADDITIONAL INFORMATION}

The rebuilding and renovation of the building was carried out according to the project: Rebuilding of buildings on Bankowa Street for the needs of the City Public Library, in the scope of the Lubuskie Voivodeship Regional Operative Program. The building-renovation works cost over $8.2 \mathrm{mln}$ PLN, of which 50\% was financed from European Union funding.

\section{REFERENCES}

1. Radziewicz - Winnicki J.: Historia architektury nowożytnej w Polsce. Klasycyzm., Gliwice, Wydawnictwo Politechniki Śląskiej 2009.

2. Andrzejewski T., Gącarzewicz M., Sobkowicz R.: Dzieje Nowej Soli. Wybór źródet i materiałów., Nowa Sól, Muzeum Miejskie w Nowej Soli 2006.

3. Andrzejewski T., Gącarzewicz M.: Nowosolskie ulice. Tom 1 A-G, Nowa Sól, Muzeum Miejskie w Nowej Soli 2009.

4. Projekt budowlano - wykonawczy Miejskiej Biblioteki Publicznej w Nowej Soli, ul. Bankowa 3, 67-100 Nowa Sól. Biuro projektowe P.U.P.I. Plan Sp. z o.o., ul. Browarna 1, 65-823 Zielona Góra.

5. Studium wykonalności dla projektu: Przebudowa budynków przy ul. Bankowej wraz z zagospodarowaniem terenów przyległych na potrzeby Miejskiej Biblioteki Publicznej w Nowej Soli wykonane przez Zachodnie Centrum Konstultingowe „Euro Invest” Sp. z o.o. w Gorzowie Wlkp.

6. www.biblioteka.nowasol.pl

7. www.nowasol.pl

\section{RENOWACJA I PRZEBUDOWA OBIEKTU NEOKLASYCYSTYCZNEGO NA PRZYKŁADZIE BUDYNKU MIEJSKIEJ PUBLICZNEJ BIBLIOTEKI W NOWEJ SOLI}

\section{Streszczenie}

Budynek Miejskiej Biblioteki Publicznej mieści się w miejscowości Nowa Sól, województwo lubuskie, przy ul. Bankowej 3. Nową siedzibę zajmuje od 2011 roku, poprzednio mieściła się w lokalu przy ul. Parafialnej i Szkolnej, która nie spełniała wymogów wygodnych pomieszczeń bibliotecznych i czytelniczych. Renowacja i przebudowa obiektu rozpoczęła się w 2007 r. i trwała 4 lata. Stuletni budynek przez lata zmieniał swoją funkcję użytkową - od willi mieszkalnej, po szpital dziecięcy, na końcu na dziecięce przychodnie specjalistyczne. W trakcie prac budowlanych 
wymieniono stropy typu Akerman na płyty betonowe o większej nośności oraz więźbę dachową, wykonaną na wzór pierwotnej. Powstał dźwig osobowy z nową płytą fundamentową, powiększono pomieszczenia biblioteczne, archiwalne oraz czytelnicze poprzez usunięcie ścian działowych. Obiekt zyskał nową elewację oraz stolarkę okienna i drzwiową. Stworzono obiekt bez barier architektonicznych dla osób niepełnosprawnych, z zewnętrzną pochylnią i platformą wewnątrz. Całość otoczona jest parkiem zwanym Ogrodem Sztuk. Budynek MBP spełnia w pełni walory estetyczne i funkcjonalne, jest miejscem spotkań kulturalnych i edukacyjnych na miarę XXI wieku.

Słowa kluczowe: Miejska Biblioteka Publiczna, Nowa Sól, Bankowa, renowacja, neoklasycyzm, przebudowa.

Editor received the manuscript: 13.04.2015 
